\title{
The Impact of Internet Big Data Era on Financial Accounting and Its Countermeasures
}

\author{
Xinjiang Zhang \\ Xi'an Peihua University, Xi'an, Shaanxi, 710125
}

Keywords: big data; financial accounting; status and countermeasures

\begin{abstract}
With the advent of the era of big data, the accounting informationization and accounting functions of traditional accounting industry and the auditing industry have changed, which has impacted the traditional accounting and auditing industry, changed the accounting and auditing methods, and promoted the reform in accounting and auditing industry. This paper focuses on the impact of accounting and auditing in the era of big data, and proposes solutions to existing problems.
\end{abstract}

\section{Introduction}

In today's "big data era" background, accounting practitioners need to acquire more knowledge to deal with the problems that may arise. Accounting personnel need to use more big data technology to solve new problems arising from management accounting. The key is to use systemic thinking and use professional knowledge to sort out the various relationships that exist between big data and the industry. The development of big data has had a great impact on accounting, and it will continue and deepen this influence in the future. In this gradual process, both accounting personnel and accounting work are never seen before. The challenge is that accountants must be able to take the initiative to meet difficulties. The work of accountants is more focused on value management and creation, providing business orientation.

\section{The Impact of Internet Big Data Era on Financial Accounting}

The Internet big data era means massive amounts of data information, which means that financial accounting work gives effective and comprehensive attention to all types of data information. Due to the more complex sources of financial data information, the information that financial accounting focuses on is more diverse. First of all, it is required to have a high degree of correlation between the sources of financial accounting data, and to ensure the provision of a large amount of effective financial information to support the smooth development of accounting and accounting work. Secondly, it is necessary to strengthen the accuracy of accounting data information, and emphasize the use of data information, focusing on the production of valuable financial management opinions around rich data information. Third, with the increase in the amount of financial data, it means that the difficulty of processing financial data and the increase of workload, only by repeatedly checking the financial data information, can effectively reduce the systematic deviation of data, it also means that financial accounting personnel will spend A lot of energy is on the review of data information.

Financial accounting work is an important means to ensure fair measurement. Only financial information can objectively reflect the status of financial operations of enterprises, in order to provide the necessary basis for relevant business management. In the era of big data, the release and update of data has become extremely rapid. On the one hand, a large amount of data has improved the accuracy and transparency of fair financial management, thereby improving the overall reliability and scientificity of financial accounting work. Requiring corporate financial accounting to conduct financial management work with more standardized means and fulfilling responsibility for financial data information means strengthening the responsibility of financial accounting work, requiring financial accounting to improve information quality, and timely release relevant data information, so as to meet upstream and downstream enterprises and Customer needs to meet the 
real financial management needs of the society.

With the advent of the era of big data, financial accounting is not only limited to ensuring accurate accounting of financial work, but also requires accountants to fully exploit the value of accounting information, and pay attention to the use of diversified and personalized methods to meet the reality of accounting work. Demand, according to the needs of different users to provide effective financial accounting information support, focus on timely screening of relevant data information, to ensure that the company's various business needs, meet the full use of financial data information.

\section{Requirements of Financial Accounting in Internet Big Data Era}

The impact of big data on financial management is incalculable. Big data not only provides conditions for reflecting business operations, but also big data will become an important advantage for enterprise development. As the department that directly generates and collects data, the enterprise accounting department should exert the important value of first-hand data. First of all, corporate finance personnel should be familiar with various types of data information, can quickly filter out valuable information from a large number of data information, pay attention to the value of various types of data information, and reflect the actual situation of business management through information. Secondly, financial management personnel are required not only to have financial management knowledge, but also to require financial management personnel to grasp the basic situation of the enterprise, to fully exploit various information in the business process, to achieve reasonable distribution of various data, and to control costs. The angle to play the value of all kinds of data information.

With the rapid development of data information technology, not only a large amount of structured data information is generated in the production and operation process of the enterprise, but also a large amount of unstructured data and special type data are generated under the support of the new data type and network technology. These data information can also generate value in financial accounting work. Therefore, accounting personnel can only respond to the characteristics of the big data era effectively by familiarizing themselves with relevant operating software and mastering the operational capabilities of unstructured data, and practically apply various data information to enterprise development. Go in. Only when financial accountants have the ability to mine data from massive data information can they better adapt to the characteristics of the big data era and effectively meet the needs of data mining.

Accounting work mainly provides services for the development and operation of enterprises. Accounting work is an important auxiliary carrier for providing decision-making information for business operations. Especially in the market environment of increasingly fierce competition, in order to improve the scientific and applicability of business management, financial managers must pay attention to changes in business decision-making, and can use big data scientifically according to changes in financial management objectives. Means, gradually promote the transformation of financial management methods, and treat data information in a diversified and complicated way, so as to exert the actual value of data information according to the diversified needs of enterprise development.

In the era of big data, financial accounting is required to re-examine financial accounting work, and it is required to effectively deal with problems in traditional financial accounting work. First of all, to improve the quality of information disclosure and improve the pertinence of accounting information disclosure, not only must reflect various explicit indicators, but also reflect various implicit data indicators. It is necessary to change the lack of anticipation of financial accounting work in the past. Secondly, with the help of accounting information to improve the accuracy of budget management, we must establish the concept of time value, focus on strengthening the management of ex ante and the event, strengthen the flexible space of accounting budget, and effectively reduce the problem of large financial accounting errors. Third, for the accounting management work system with a sound background in the era of big data, it is necessary to realize the effective division of accounting duties and responsibilities, and achieve comprehensive 
guidance on the functions of various accounting departments.

\section{Coping Strategies of Accountants in Internet Big Data Era}

In the context of the big data era, it is the first problem that needs to be solved to build a cloud-based information analysis system and to explore accounting data. First, lay a solid foundation for the software and hardware required for cloud computing, develop and improve relevant national standards for cloud computing services, build relevant cloud computing platforms, and vigorously develop the application of cloud technologies in its accounting field; secondly, Under the leadership of the central government's funds, technology and personnel, with the support of the government, establish a unified information analysis system; finally, the relevant technologies for the collection, storage, and output of data information are formulated by the state, and are controlled by local and enterprises. Unified standards to implement and implement.

In the context of big data, accountants should strengthen their understanding of information security, and business managers should also pay enough attention to the fact that information security will have a profound impact on the management of enterprise accounting systems and future development. The traditional accounting objective is mainly to reflect the past information, and use the historical static structure data to analyze the data information generated in the past. Therefore, the traditional accounting system can only provide historical accounting information, which obviously cannot provide sufficient support for investors' decision-making. The ability of big data to have data includes extremely fast processing speed information. In the era of big data, huge amounts of information that emerge through the system can be reflected in accounting information in a timely manner. Therefore, the speed of data analysis in the era of big data is immediacy, and accounting information requires such real-time data information. In the era of big data, we can use real-time changes in dynamic accounting information to complete real-time monitoring of business operations. From forecasting to decision-making, we can better control and analyze, while carefully handling encryption operations and improving accounting information security.

The management of the company has a major responsibility for providing more up-to-date accounting talents in the context of the big data era and providing more assistance to the growth of accountants. Enterprises should start in the following two aspects: First, clarify the functions of the post, put forward specific requirements for accountants in terms of knowledge and ability, and provide incentives for accountants to receive re-education; second, the company will assess the corresponding aspects when recruiting Find more professional accounting personnel, not only have good accounting staff professional quality, but also have excellent accountants' professional responsibility and higher professional ethics.

The first is to provide better college education. In the era of big data, colleges and universities can be said to be the main training base for accounting personnel, and they must be strictly controlled. Colleges and universities should grasp the key points, and pay sufficient attention to the students' accounting knowledge and computer knowledge, and better integrate the two contents. Strengthening the training of accounting information and providing computer-operated learning, it is necessary for schools to focus on the combination of accounting expertise and computer knowledge. In addition, schools should also pay attention to the education of students in accounting majors. In order to promote the better application of big data in the audit field, it is necessary for decision-makers to master professional audit knowledge and conduct a reasonable analysis of the data. At the same time, it is necessary to break the traditional audit analysis situation and optimize the upgrade process. In addition, because the confidentiality of big data is relatively poor, the security of data during generation and transmission should be guaranteed. Since the application of big data in China is still in its infancy, in the application process, the human and material resources

should be scientifically planned. The internal audit department should establish long-term development goals and improve data analysis. Ability to increase the emphasis on audit work. 


\section{Conclusion}

The rise of the era of big data has brought certain influence to the development model and development direction of enterprises. It has changed the original accounting and auditing modes of enterprises, and brought opportunities and challenges to the accounting and auditing work of enterprises. Faced with such a background, Enterprises should make full use of the advantages of big data to provide real-time decision-making for the development of enterprises and solve problems in the management of enterprises. At the same time, in the management of enterprises, big data should be regarded as an important asset in the development of enterprises, and integrated into the internal assets of enterprises to achieve effective management of corporate assets, laying the foundation for the smooth development of corporate accounting and auditing, and promoting The healthy development of the company.

\section{References}

[1] Chen Juanying. The Impact of Internet Big Data Era on Financial Accounting [J]. Accounting Research, 2015, 14: 80-81.

[2] Lin Rong. The Impact of Big Data Era on Management Accounting and Its Role [J]. Enterprise Reform and Management, 2015, 24: 106.

[3] An Yanli. The Impact of Big Data Era on the Quality of Enterprise Accounting Information [J]. Financial Supervision, 2013, 13:41.

[4] Yao Wei. Thoughts on accounting work under the age of big data [J]. Chinese Management Information, 2015 (17).

[5] Zhao Ping. Internet financial background changes in corporate financial management [J]. Cooperative Economy and Technology, 2015 (16). 